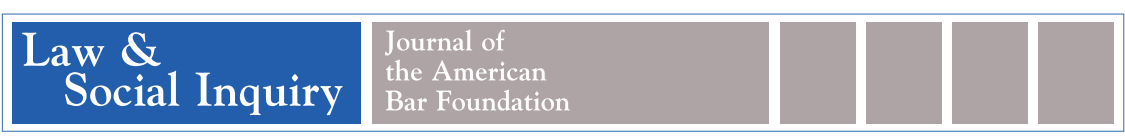

Law Eु Social Inquiry

Volume 43, Issue 3, 647-677, Summer 2018

\title{
Very Long Engagements: The Persistent Authority of Bridewealth in a Post- Apartheid South African Community
}

\begin{abstract}
Michael W. Yarbrough
This article examines the persistent authority of lobola, the customary practice for forming marriages in many South African communities. South African marriage rates have sharply fallen, and many blame this on economic challenges completing lobola. Using in-depth, qualitative research from a village in KwaZulu-Natal, where lobola demands are the country's highest and marriage rates its lowest, I argue that lobola's authority survives because lay actors have innovated new approaches for pursuing emerging desires for marriage via lobola. I argue that dyadic narratives of marriage increasingly circulate alongside "traditional" extended-family narratives, especially among the young women who strongly support lobola while yearning for genderegalitarian marriages. My argument synthesizes actor-oriented analyses of legal pluralism with Ewick and Silbey's theorization of lay actors' role in producing legality to illuminate how lay actors contribute not only to the form and content of different legal systems, but also to the reach of their authority.
\end{abstract}

\footnotetext{
Michael W. Yarbrough is an Assistant Professor of Law \& Society in the Political Science Department of John Jay College of Criminal Justice (City University of New York/CUNY), and he also serves as a Research Associate of the Department of Sociology in the Faculty of Humanities at the University of Johannesburg and a Board Member of CLAGS: The Center for LGBTQ Studies. He can be contacted at myarbrough@jjay.cuny.edu. The research for this article was supported by a FulbrightHays Doctoral Dissertation Research Abroad (DDRA) Fellowship, a PSC-CUNY grant (\#67688-00 45), the Provost's Office of John Jay College of Criminal Justice, and the Faculty Fellowship Publication Program at CUNY. The research plans were approved under IRB Protocol \#0912006128 at Yale University and IRB Protocol \#625837-1 at the City University of New York. Earlier versions of this article were presented at Harvard University, Yale University, the University of Cape Town, the University of Delaware, and New York Law School and at several conferences. The author gratefully acknowledges the feedback of those audiences, as well as helpful comments on written drafts from Julia Adams, T. W. Bennett, Debbie Budlender, John Comaroff, Lauren Coyle, Brady G'Sell, Chuma Himonga, Mark Hunter, Anne Kornhauser, Chrysanthi Leon, Sindiso Mnisi Weeks, Elena Moore, Mojúbàolú Olufúnkè Okome, and Philip Smith. For research and transcription assistance, he thanks Qiniso Kunene, Thandeka Majola, Democracy Mthembu, Hlentela Mthembu, Mfanafuthi Mthembu, Nomsebenzi Gladys Mthembu, Nomvula Mthembu, Nonkululeko Mthembu, Sifiso Mthembu, Patrick Mthombeni, Sisanda Msekele, and Lwando Scott. Most of all, he thanks the Maqongqo residents who shared their time and stories with him.
} 
"Where are the lobola cattle? The sun is setting...."

That's what Thandiwe said. She said, "A man is his cows.

I want children, I want a home. Our traditions are important to us.

I don't want to just live together with you.

Stop playing with me and with my love...."

I love Thandiwe. I dream of her. I wake by her.

I love her, my darling, darling Thandiwe....

I've long been working in the mines, digging for gold....

But still I don't have money ...

My father's cows are gone. What happened to my father's land? ...

Where are the lobola cattle....We should follow our cultural laws....

We should marry by our laws.

Caiphus Semenya, “Ziphi'nkomo” (1996)

\section{INTRODUCTION}

The first time I attended a Zulu wedding, the groom was already dead. His physical absence from his own wedding, though sad, was unremarkable. During the fieldwork for this article I encountered countless engagements of a decade or more, including others also punctured by death. A generation of young adults in the South African village where I centered my fieldwork experiences marriage today mostly as a state of perpetual delay, an enduring aspiration but vanishing achievement. To reach marriage after death is, in local eyes, fortunate. Most never reach it at all.

Many in my field site of Maqongqo and in the province of KwaZulu-Natal more broadly blame marriage's decline on the difficulties of the core customary process through which recognized marriages are formed (Hosegood, McGrath, and Moultrie 2009; Posel, Rudwick, and Casale 2011; Posel and Rudwick 2014a). Known in proper isiZulu as ukulobola and across several languages as simply lobola, ${ }^{2}$ this process centers on a large gift of "cattle," today usually at least partly in the form of cash (Dlamini 1983, 223), from the groom's family to the bride's. Grooms themselves increasingly assumed responsibility for this central gift, called ilobolo, when colonial political economies pushed African ${ }^{3}$ men into wage labor (Carton 2000; Hunter 2010), but massive unemployment has ravaged most of post-apartheid South Africa, Maqongqo included. While many young men today begin paying

1. Translated lyrics from popular 1980s song. Original isiZulu and isiXhosa lyrics transcribed and translated by Lwando Scott. Original transcription available from author on request.

2. Ukulobola is an infinitive, and -lobola is the verb denoting the action of paying ilobolo, the isiZulu noun for the bridewealth payment itself. Lobola has become a lingua franca term across ethnic groups for both the overall process and the specific bridewealth payment. For clarity's sake, in this article I use the term lobola for the overall process and ilobolo for the specific payment from the groom or his family to the bride's family.

3. Racial terminology in South Africa is complex, and in particular the term "black" has had different referents in different periods. I use the terms "African" or "black African" to refer to those people whose genealogy and/or phenotype would generally lead them to be considered potential subjects of African customary law. This article focuses primarily on those Africans who speak isiZulu, and especially those living in what is now the province of KwaZulu-Natal. 
ilobolo, few get far enough that the families permit a wedding. And so, I was repeatedly told, "Marriage has finished."

And yet lobola persists, still marriage's central pillar if now perhaps also its biggest obstacle. Decades of scholarship have documented lobola's significance for a wide range of southern African people: rural and urban, young and old, men and women (Murray 1977; de Haas 1987; Walker 1992; Burman and van der Werff 1993; Vorster et al. 2000; Shope 2006; Posel, Rudwick, and Casale 2011; Nkosi 2011; Rudwick and Posel 2014, 120). ${ }^{4}$ This is especially true of KwaZulu-Natal, where lobola norms are perhaps South Africa's strongest and ilobolo amounts its highest (Burman and van der Werff 1993; Hosegood, McGrath, and Moultrie 2009; Posel, Rudwick, and Casale 2011). ${ }^{5}$ Some do criticize lobola, and many criticize how others practice it, but virtually all Africans in KwaZulu-Natal must contend with the value others place on it (Posel and Rudwick 2014a, 2014b; Rudwick and Posel 2014). As the core grammar and process through which a range of recognized kinship obligations are formed, lobola functions in Maqongqo and similar places not merely as a cultural attribute of marriage but, more deeply, as a law-like authority over it. That most isiZulu-speakers include lobola under the term for law, umthetho, underlines the point. ${ }^{6}$

This article seeks to explain lobola's enduring authority despite the role locals ascribe to it in the perceived crisis of marriage. Part of the answer lies, unsurprisingly, in lobola's agreed-upon status as tradition and in the capacity of elder generations to mobilize what they consider traditional narratives of African marriage as uniting two extended families rather than two individuals, a narrative that allows elders to maintain legitimate oversight, via lobola, of younger generations' family formations. But lobola is also strongly supported by the many young people whose marriages it delays. This includes many young women who desire what they call "50/50"-gender-egalitarian-marriages and who pursue these desires via lobola. These women's views point to a key element in lobola's post-apartheid persistence, for they rest on an underappreciated narrative that frames lobola not only as a traditional process between extended families, but also as a more individualized, dyadic process between a would-be husband and wife.

This narrative manifests, for example, in some young women's backstage negotiations to reduce their families' ilobolo requests of a desired suitor, or in the ways some young women, like Thandiwe in the song that opened this article, implicitly treat lengthy lobola processes as a test of their intended husbands' emotional commitment and financial discipline. Also deployed by many men, this dyadic narrative revolves around norms of marital autonomy and even gender equality that draw on several influences, including post-apartheid tropes of democracy and the constitution. In this way, normative motivations drawing on post-apartheid state law help shape a

4. Lobola's salience does vary across region and other factors, and the approach I use here could help illuminate the historical and interactional processes that produce that variation.

5. As I discuss below, this likely reflects colonial regulations exclusive to that region. I argue that local Africans' responses to those regulations became settled as customs that, among other effects, apparently exert upward pressure on ilobolo amounts.

6. The song in this article's epigraph does this in the plural form: imithetho yesintu, that is, cultural laws. 
core practice of customary law, introducing new possibilities into lobola's legible repertoires of action and thereby neutralizing a potential threat to its authority.

That state law should shape customary law is no surprise. The interesting dimension here is that the influence works not through direct enforcement of state marriage statutes, but through laypeople's interpretations of, inter alia, abstract rights discourses. Indeed, the most specifically relevant statute, the Recognition of Customary Marriages Act (RCMA) passed in 1998 to authorize state registration of customary African marriages, is virtually unknown in Maqongqo and, in any event, says little about lobola. It is the broader constitution that matters here, and even that not through concrete enforcement but through particular forms of rights consciousness (McCann 1994) many Maqongqo residents have developed under its aegis. This particular transformation constructs a particular relationship between state and customary law, and laypeople play a key role in constructing this relationship. At the same time, this transformation follows several others in the colonial and apartheid periods-for example, the shift of responsibility for paying ilobolo from grooms' fathers to grooms themselves, or the decline of taboos against brides knowing the terms of their own lobola - each of which also bears the marks of laypeople's actions while reconstructing the relationship between state and customary law. Lobola's persistent authority from pre-colonial to post-apartheid rule depends, I argue, on a notable capacity for adaptation located in the individual and family actions that propel it. As they form, perform, renegotiate, contest, and abandon lobola agreements, and as they rely on the grammar of lobola when assigning marital status, these individuals and families not only deploy established repertoires of lobola actions, but also innovate new practices suited to changing constraints, capacities, and desires.

The question I pose here about lobola's persistence is one case of a broader problem in law and society scholarship, namely, how to explain the complex combinations of constancy and change that characterize even relatively unified legal orders, let alone situations such as this where multiple legal systems operate in one setting. The very recognition of such situations of legal pluralism, as such copresence of multiple legal systems has come to be called (Griffiths 1986; Merry 1988), represented an important advance. By displacing assumptions that the state monopolizes law, legal pluralism scholarship has sensitized us to a wider array of practices and institutions constituting legal life and complexified the conceptual models we use to understand these practices and institutions. In some four decades of legal pluralism scholarship, however, much of the theoretical energy has focused on binary questions of disciplinary gatekeeping-Is this law or is this not?-obstructing the inquiries most powerfully enabled by the concept of legal pluralism, namely, precisely how and why different normative orders vary and how they interact. As Franz and Keebet von Benda-Beckmann put it, legal pluralism is "primarily a sensitising concept" $(2006,14)$ that "does not obscure, but rather reveals relevant distinctions between normative orders" (17).

7. The RCMA authorizes state registration of marriages concluded "in accordance with a system of African customary law," but is deliberately silent about what such accordance requires. Although one clause of the RCMA specifically directs the registering officer to record the amount of ilobolo, lobola was not specified as a requirement for state validity, in order to leave it a private choice (Goldblatt and Mbatha 1999). 
As the sensitizing power of the concept has become increasingly settled, more attention has turned to tracing such distinctions and their sources. Of particular importance to my argument here is one strand of such inquiry, centered especially in legal anthropology, that focuses on the actions of those who use (or do not use) particular legal systems in a pluri-legal setting. Such actor-oriented approaches (see, e.g., Griffiths 1998; von Benda-Beckmann and von Benda-Beckmann 2006; JeanBouchard 2014) foreground the strategic actions of individuals negotiating legally plural orders in order to understand how such actions help change legal systems and the articulations among them (Turner 2015). The kinds of changes canvassed in this work include the substantive content of legal rules, the actors authorized to make or administer law, the relative institutionalization of different normative systems, and the differentiation of legal expertise from everyday knowledge (von Benda-Beckmann and von Benda-Beckmann 2006, 13-14). These are important questions, yet they remain, despite the emphasis on actors' actions, primarily focused on legal systems themselves. What is less addressed is how different systems and the norms they administer acquire, maintain, or lose influence and authority among those they govern. Although the relative salience of different norms is an important theme in actor-oriented work on legal pluralism, it more commonly appears as an input into the causal story rather than an outcome of it. In many actor-oriented arguments, lay actors influenced by a particular norm circulating in their pluri-legal environment pursue material or symbolic goals shaped by this norm by turning to those institutions they perceive as most useful for the relevant goal. Such analyses are illuminating, and the story of lobola I tell below shares much in common with them. But they tend to bracket the question of why actors feel a particular system and its norms to be salient for them.

I find helpful resources for addressing this problem in Patricia Ewick and Susan Silbey's work theorizing the role of everyday legal actions in producing and reproducing what they call "legality," by which they mean the multifaceted presence of law as a feature of social life $(1998,17,22)$. In particular, Ewick and Silbey attribute legality's enduring presence to the diverse yet patterned narratives people offer about it, arguing that this narrative diversity allows legality to survive events that challenge its own official story. If a "before the law" form of legal consciousness, as they call it, portrays law as objective and just, the wide availability of pragmatic "with the law" and resistant "against the law" narratives helps people make sense of experiences with law that violate before-the-law ideals. In this way, they argue, narrative diversity helps law maintain its appearance of coherence and authority despite a much messier and more diverse reality (Ch. 7).

Many scholars have drawn on Ewick and Silbey's work, but most have focused on their before/with/against typology without deeply engaging the theoretical model that grounds legality's persistence in these diverse forms of consciousness (Silbey 2005). It is this underlying theoretical model that animates my argument here. As summarized above, I argue that lobola remains a legitimized form of customary law not only because of its traditional narrative, but also because of alternative narratives that South Africans have developed for it using cultural resources of diverse provenance, including their own understandings of post-apartheid state law. In Ewick and Silbey's paradigm, the alternative, more individualistic narrative of 
lobola draws on "schemas" (see Ewick and Silbey 1998, 39-43) of romantic love and of individual, egalitarian rights.

Through their behaviors influenced by these schemas, young women and others introduce new variations into lobola's established repertoire of legible action. As these variations become more widespread, they sediment into a relatively patterned feature of lobola, subtly transforming its content and thereby facilitating its persistence in changed circumstances. Like the work of the von Benda-Beckmanns and other actor-oriented scholars of legal pluralism, Ewick and Silbey's model rests on theoretical commitments to the role of lay actors in legal life and to practicecentered models of the relationship between structure and agency. My argument here attempts to activate these common roots into a more deliberately synthesized connection, gesturing toward what we might call an actor-oriented model of the production of pluri-legality.

The next section briefly reviews the history of lobola, focusing especially on the area now known as KwaZulu-Natal. I then discuss my methodological approach, including some discussion of Maqongqo's particular fitness for a study of this topic. The empirical discussion begins with the orthodox narrative of lobola, whose emphasis on extended-family relations continues to circulate widely and explicitly in Maqongqo, before turning to the less-noticed, dyadic narrative of lobola that I argue helps sustain its enduring authority today.

\section{INTRODUCING LOBOLA}

Lobola is a complex, multistage process involving a series of gifts from each family to the other, the most important of which are marked by public ceremonies and feasts. The precise elements differ across region and even family (Dlamini 1983), but certain commonalities extend across different isiZulu-speaking communities. Chief among these is lobola's centerpiece, ilobolo, the large gift of cattle from the groom's family to the bride's that carries the core meanings of the overall process. The range and contours of these meanings have changed over time, but the most commonly mentioned derive from the orthodox narrative framing African marriage as a relation not only between bride and groom but between the kin, both living and dead, arranged around them (Evans-Pritchard 1931; Steyn and Rip 1968; de Haas 1987; Ansell 2001; Rudwick and Posel 2014). By moving from her natal to her marital home, the bride creates a link between the two families, as do the cattle that move in the opposite direction (Guy 1990). This unification of families introduces a stranger whose presence is necessary to extend the husband's family line forward in time, but also threatening to its existing order (Kuper 1982).

In the orthodox narrative, lobola both pragmatically and cosmologically eases this paradox. It represents gratitude from the groom's family to the bride's for raising her well (de Haas 1987; Ansell 2001; Rudwick and Posel 2014) and, by being paid over time, stages ongoing interactions and obligations between the families that help them become acquainted with and support each other over an extended period (Dlamini 1983; Burman and van der Werff 1993). Similarly, lobola is also 
understood as the process that introduces the bride to the deceased ancestors of her new family, allowing them peacefully to welcome her into their home.

While these meanings continue to dominate explicit conversations about lobola, new meanings have also clearly emerged over decades of colonial, apartheid, and now post-apartheid rule. The most sustained recent investigation into these meanings comes from an interdisciplinary team of researchers led by Dorrit Posel. Their work confirms that both marriage and lobola remain deeply valued by the isiZulu-speaking people they interviewed in-depth, who frequently invoked lobola's orthodox purposes: circulating resources within and across families, building caring relationships between the families (Rudwick and Posel 2014, 130-31), constructing appropriate ethnic and gendered identities (125-29), and maintaining good spiritual relations with deceased ancestors (131-32).

At the same time, Posel's participants also expressed several concerns about lobola. A particularly widespread worry was that lobola has contributed to declining marriage rates (Posel, Rudwick, and Casale 2011) and, indeed, statistical data are consistent with that hypothesis, finding the country's lowest marriage rates in the province of KwaZulu-Natal, where lobola is especially important for reasons I discuss below (Hosegood, McGrath, and Moultrie 2009; Casale and Posel 2010; Posel, Rudwick, and Casale 2011; Posel and Casale 2013). A related critique suggested that lobola has become commercialized, with some women's families treating it as an economic opportunity by ratcheting up their ilobolo requests (Rudwick and Posel 2014, 130; see also Dlamini 1983, 228, 230). Another set of concerns, expressed by some women, suggested that lobola symbolically and materially disadvantages women, for example, by legitimating abuse by husbands who see themselves as having paid for the respect and domestic labor of their wives (Rudwick and Posel 2014, 128-29). These various critiques indicate that lobola's meanings have multiplied over time, a finding that echoes in fuller form the work of numerous other scholars (see, e.g., Walker 1992; Burman and van der Werff 1993; Shope 2006).

Meanwhile, social geographer Mark Hunter's work suggests another significant meaning of lobola for many: love. Hunter $(2010,16)$ argues that many young African women today view monetary assistance as a kind of materialized devotion he calls provider love. Producing relationships that defy simplistic dichotomies between transactional sex and authentic affection, provider love draws heavily, Hunter suggests, from lobola's enactment of similar ideas on a grander scale ever since migrant labor forced husbands to pay their own ilobolo and maintain their rural households from afar (see also MacKinnon 1999). Hunter's argument constructs perhaps the most nuanced existing scholarly description of lobola's complex contemporary meanings, capturing especially well both how women are constrained by institutional structures and cultural norms that leave them dependent on men's financial resources, and how these women navigate such constraints through the idioms culturally available to them. My interpretation here extends Hunter's while pushing one step further, exploring not only the more material provider love connotations of lobola, but also the more emotional and intimate romantic love connotations it now carries for many. More broadly, in relation to the broader literature on lobola, I place special emphasis on the underrecognized dyadic and individualist themes running through its practice, threads that I suggest are essential to its contemporary persistence (see also Thomas and Cole 2009, 22). 
These multiplying meanings emerged against the backdrop of colonialism and apartheid, which directly regulated lobola and more broadly disrupted African families through industrialization, urbanization, and the white supremacist migration and land policies enacted to manage these trends. No southern African region saw more systematic colonial regulation of lobola than the Natal Colony. Sir Theophilus Shepstone, the colony's Native Commissioner for several decades in the mid-nineteenth century, innovated indirect rule tactics that incorporated "native" structures into the colonial apparatus, a technique that would eventually characterize British colonialism around the globe (Mamdani 1996; Myers 2008). His strategy of partial incorporation struck many of his colonist contemporaries as uncomfortably sympathetic to Africans, yet it would ultimately dominate colonial and apartheid South African approaches to customary law for over a century. Regarding lobola specifically, Shepstone's most significant intervention was to limit to ten the number of cattle transferred as ilobolo in commoner marriages, plus one beast for the bride's mother; ilobolo cattle above that amount could be seized by the chief of the bride's family for his own use (Welsh 1971, 79; Dlamini 1983, 230-31; Lambert 1989). Intended to erode the consolidation of large herds and polygynous families by older, richer men, this upper limit quickly became ilobolo's standard when daughters' families demanded as many cattle as colonial law would allow (Dlamini 1983, 234) ${ }^{8}$-an early example of lay responses to state regulation that would transform the practice of lobola. The ten-cow limit continued after the colonial era, incorporated into the law of Natal province by the nationwide Native Administration Act (NAA) enacted in 1927 by the young Union of South Africa. ${ }^{9}$ When the apartheid government carved the purportedly independent "nation" of KwaZulu out of Natal province in the 1970s, that jurisdiction's parliament once again incorporated the ten-cow limit into its own KwaZulu Code of customary law. Meanwhile, on the ground, daughters' families continued to rely on this maximum as the starting point for negotiations. Many throughout KwaZuluNatal today, including in Maqongqo, continue to believe that complete ilobolo comprises $10+1$ cows (Rudwick and Posel 2014). ${ }^{10}$ Even more interestingly, the colonial origins of the $10+1$ number have been forgotten, and it is now widely understood as a cultural requirement.

A separate strand of Natal Colony regulations implicated lobola less directly but nonetheless helped shape its practice and meanings. Like many other Africans, isiZulu-speaking people at the time of colonization typically saw marriage as a "process not an event," believing a couple to become progressively more married over time as they passed through life stages together (Comaroff 1980). Lobola embodied this idea, for it unfolded over time and was ideally never fully completed,

8. Generally, it is expected that the ten-cow number would be reduced if the woman is not a virgin or, especially, if she has borne children by another man.

9. The NAA only recognized customary marriages for certain limited purposes and called them customary unions rather than marriages (Posel 1995; Albertyn and Mbatha 2004). Several subsequent executive proclamations, authorized by the NAA, updated the Natal Code of customary law but left in place all provisions discussed in this article. For more detail, see Bennett (2004, 46-47, 70-74, 190-91). The RCMA requires only that state-recognized customary marriages be valid "according to customary law," rendering uncertain the current status in state law of any ilobolo standard.

10. As discussed below, ilobolo today primarily takes the form of cash, but negotiated amounts are widely denoted in a vocabulary of cows. 
as reflected in the common saying in isiZulu and other Nguni languages that "ilobolo aliqedwa": "ilobolo is not [ever] finished." "This processual understanding of marriage immensely frustrated colonial administrators, however, who prized the crisp certainty of a clear wedding ceremony. Shepstone's regulations thus defined a customary marriage to exist only after ilobolo was paid in full and the bride publicly consented to marry at an African wedding ceremony, after which the chief's iphoyisa (policeman) registered the marriage in writing (Dlamini 1983; Bennett 2004). Also incorporated into Natal law with the NAA and later into the KwaZulu Code, these requirements were amended by the RCMA's own registration provisions but remain common in some communities today, including Maqongqo, where many spontaneously recounted them to me in precise detail.

The implications of these regulations for lobola were complex. On the one hand, they directly incorporated lobola into state marriage regulations, perhaps helping explain why lobola remains more widely valued and ilobolo more expensive in KwaZulu-Natal today than elsewhere in the country, where similar state laws never existed (Posel, Rudwick, and Casale 2011). They also, together with the tencow limit, encouraged in at least some African communities of the colony a more event-based notion of marriage as something that is concluded at a particular moment in time, namely, the public ceremony that follows lobola's completion. One must not overstate this effect, for evidence exists that processual notions of marriage still circulate in some KwaZulu-Natal communities today (Cousins 2013; Mnisi Weeks 2013). ${ }^{12}$ There nonetheless has been a clear shift in many communities toward more event-based understandings, and it is likely that these colonial regulations helped encourage that. What the regulations did not create, however, was a sense that the state held exclusive or even primary authority over recognized marriage formation. All existing scholarly evidence indicates that this primary authority remains with lobola. A marriage can be a marriage without recognition from church or state, but almost never without lobola.

Perhaps the largest transformation wrought in lobola practices by settler colonialism derived not from direct legal regulation, but from the violent replacement of a largely pastoral economy with one based on (low) wages earned primarily through migrant labor for white employers (Murray 1977, 1981; Hunter 2010). This transition was forced in part through private property laws forcibly conveying African farmlands into white hands (Beinart, Delius, and Trapido 1986; Hunter 2010) and hut taxes assessed for each building on an African family's homestead (Welsh 1971; MacKinnon 1999). ${ }^{13}$ Payable only in cash, hut taxes both discouraged polygyny-each wife typically living with her uterine children in her own hut-and virtually required men to work for white employers. The rise of cash did not end ilobolo, but it did transform both its primary medium and the social relations

11. Rudwick and Posel $(2014,130)$ cite their participants as using the similar "Amakhoti akaqeda," that is, "Wives do not finish."

12. Similarly, Rudwick and Posel $(2014,130)$ report that many participants regard an expectation that lobola be completed before a wedding to be "untraditional."

13. Historian Nafisa Essop Sheik (2014) points out that hut taxes constituted a large portion of Natal Colony revenue. She argues that, far from discouraging polygyny, this tax actually made the colony dependent on it. 
surrounding it. To the first point, ilobolo transfers are now largely conveyed in cash payments that, while still often narrated in the vocabulary of cows, are almost inherently more fungible than actual, living cattle. The rise of cash, and of wage labor more generally, has also pushed responsibility for paying ilobolo from the groom's father to the groom himself (Hunter 2010). ${ }^{14}$ For many decades this helped to release younger generations from elders' control, giving young men more control over their choice of wives and helping foster the shift toward more dyadic narratives of marriage. The precipitous decline of wage employment from the 1970s until now, however, has left many young men unable to pay ilobolo, suspending them in a kind of prolonged adolescence (Morrell 2001; Shefer 2007; Hunter 2010, 94). During my Maqongqo fieldwork, the ironies of this transition appeared on a popular nightly soap opera called, aptly, Generations. In a plot that would have been almost totally incomprehensible a century earlier, a young urban professional worried what it meant for his manhood that he had to turn to his father, a Zulu chief, to help pay his own ilobolo. The shift from fathers to sons under colonialism had by this point become another taken-for-granted requirement perceived as cultural in origin.

All these pressures left lobola transformed yet resilient in the 1990s, when perceived tensions between constitutional gender equality guarantees and other constitutional provisions protecting cultural practices and institutions raised new questions about lobola's place in the post-apartheid order (see, e.g., Sachs 1990; Bennett 1994). The legal debate regarding lobola was largely settled with the RCMA's 1998 enactment. Although gender-rights activists and African traditionalists struggled over many issues in the RCMA process-most importantly the legal status of polygyny and the authority of traditional versus state institutions over customary marriages (Yarbrough 2015)-leading stakeholders generally agreed that lobola should be left a primarily private matter, not explicitly required for a staterecognized customary marriage to exist (Albertyn and Mbatha 2004). In any event, the RCMA's concrete impact appears to have been minimal thanks both to irregular implementation (de Souza 2013) and to the widespread practice in many regions of so-called dual weddings that combine African rites, including lobola, with Christian wedding ceremonies (Mbatha 1997). This practice is more common in some areas than others, owing perhaps to differential rates and forms of Christianization. Where it prevails, the Christian ceremony is usually recognized by the state under the mainstream Marriage Act, in place since 1961, which eliminates any practical need for the RCMA as long as the marriage is monogamous. So entrenched is the dual-wedding ideal in many places that it constitutes the operative custom for forming an African marriage, yet another sedimented outcome of lay responses to state and, in this case, religious law.

\section{INTRODUCING MAQONGQO}

The dual-wedding custom worked out a place for lobola in colonial- and apartheid-era pluri-legal orders that has persisted into the post-apartheid era.

14. A rinderpest epidemic in the late nineteenth century decimated cattle stocks, further facilitating the shifts examined here (Carton 2000, 2006). 
Marriage, meanwhile, has become dramatically more elusive. For example, demographers Christine Mhongo and Debbie Budlender (2013, 184) estimate that among African females aged fifteen and over, only 26.1 percent had never been married in 1921, but in 2001 that same figure was 49.3 percent. The drop is even clearer when looking at women aged fifty and over: in 1921, only 2.4 percent had never been married, but in 2001 that figure was 15 percent. Maqongqo is no exception to this decline. Of the 909 individuals age fifteen and over in Maqongqo counted by the 2011 census, only 172 were recorded as currently married. Just thirty-eight were widowed and five divorced or separated, while fifty-six were "living together like married partners" (personal communication from Stats SA to author, November 5, 2015). The remaining 638, a full 70 percent of the total, were recorded as "never married."

As it happens, census surveys were conducted during my first phase of fieldwork, and census field staff told me they were instructed to count as married those who had completed at least one of three possible wedding ceremonies: African, church, or court. Accordingly, while it is virtually certain that some of those 638 "never married" and fifty-six "living together" had begun lobola, and some may even have considered themselves as (somewhat) married, likely none of them had celebrated a formal wedding. ${ }^{15}$ Regarding change over time, data cross-tabulating marital status with age are unfortunately not publicly available for Maqongqo. Nonetheless, it is clear that marriage is almost unheard of among Maqongqo residents in their twenties and thirties. If exceptional social status was once signaled by marrying a particularly desirable spouse or throwing an especially elegant wedding, today the mere fact of marrying does this. ${ }^{16} \mathrm{I}$ witnessed only one wedding in Maqongqo across two trips of fieldwork totaling eleven months, celebrated by a groom who, after growing up there, had left to start his own successful company. ${ }^{17}$ Almost all young adult respondents still lived with their parents or grandparents, usually to their own and their elders' annoyance. With child and old-age grants meagerly filling some of the gap left by unemployment, many households evinced a female-centered, even matriarchal character (see also O'Laughlin 1998; Mosoetsa 2011; Khunou 2012; Dubbeld 2013).

My original purpose for visiting Maqongqo was not to study marriage's decline per se, but the impact, if any, of the RCMA on the ways South Africans observing customary law understood marriage and other kinship relations. The broader project from which this article is drawn compares observers of customary law to South Africans who identify as lesbian, gay, bisexual, and/or transgender (LGBT), who also enjoy recently expanded access to state marital recognition, in their case through the Civil Union Act of 2006. The difference between the two groups is stark, with the new marriage statutes having a big impact on the ways LGBT South Africans

15. Similarly, some of those counted as just "single" rather than "living together as married partners" had probably begun lobola, but not progressed far enough to move in together or celebrate a wedding ceremony.

16. Similar observations have been made about the United States (Edin and Kefalas 2005).

17. The wedding that opened this article occurred in a nearby village among the extended family of some respondents. I also attended two lobola ceremonies, one in Maqongqo itself and one in Pietermaritzburg with the extended family of another Maqongqo resident. 
imagine kinship, but almost none for residents of Maqongqo. If the comparison sensitized me to the persistence in Maqongqo of well-established ways of forming marriages, the virtual collapse of marriage there rendered that persistence increasingly puzzling. Accordingly, I followed my first round of Maqongqo fieldwork with five weeks of follow-up research focused specifically on the persistence of lobola.

In my first phase of fieldwork, conducted from April to November 2011, I interviewed fifty participants of varied marital status ranging in age from eighteen to their early eighties, using approaches from new kinship studies in anthropology influenced by the work of David Schneider (1968, 1984; see also Weston 1991) to understand the range of important people in participants' lives and the place of marriage within those constellations. In the second phase, conducted in July and August 2014, I interviewed nineteen people about their direct involvement in their own or their children's lobola negotiations. Five participants were interviewed in both phases. I conducted all interviews myself in isiZulu, with interpretation help by my research assistants when necessary. In each interview, the research assistant was a friend of the interviewee, an approach I adopted on the advice of other ethnographers working in the region as the best way to facilitate trust around the questions I intended to ask. In both phases, I lived with a Maqongqo family, and my interview interpretations are thus further supported by participant observation in daily life and at political, religious, and community events including weddings and funerals.

Before turning to these data, it is worth introducing Maqongqo itself more fully. Lying within easy reach of urban areas and featuring strong cooperation between civil and customary legal structures, Maqongqo is the sort of place where one would expect so-called traditional and modern ways to have interpenetrated. The road to Maqongqo winds from the provincial capital of Pietermaritzburg through several kilometers of white-owned, kelly-green quilts of sugarcane until the vista opens up onto the less famous of South Africa's two Table Mountains, its gentle front-facing slope dotted with the cone-roofed huts that epitomize rural South Africa, alongside a growing number of more contemporary rectangular buildings. When I first visited briefly in 2004, the road to town was brown and muddy. By the time I returned for fieldwork in 2011, it had been paved, cutting auto travel time into town to under half an hour. Were there more jobs to be had, this development might well have transformed Maqongqo into a commuter suburb. The few residents with stable jobs do inhabit it that way, sleeping in Maqongqo and working in town as domestic workers, gardeners, or-for those with plenty of English and more luck-sales clerks at the mall or casino. The vast majority of Maqongqo residents commute less frequently, collecting their monthly child or disability grant from government offices, buying groceries, or splurging at a pub or fast-food restaurant. Maqongqo is thus punctuated by the rhythms of urban life but not (yet?) engulfed by them.

This ambiguity has grown with post-apartheid development, as the village's many supporters of the ruling African National Congress (ANC) repeatedly reminded me. "Amanzi, ugesi, umgwaqo," went the refrain of post-apartheid amenities brought to Maqongqo by the ANC: running water, electricity, and the aforementioned road. The village's connection to the ANC runs deeper than most. The current chief's late father, Mhlabunzima Maphumulo, played an extremely 
important role in regional politics and a not insignificant one on the national stage as the anti-apartheid struggle wore on, increasingly aligning himself with the more progressive politics of the United Democratic Front (UDF), more or less the ANC's presence in South Africa during the years it was legally banned (Kelly 2012, 244316). His family's ties to the ANC live on today, facilitating unusually strong cooperation between customary and state structures. Among other things, the mayor of the municipal government whose boundaries include Maqongqo, Thobekile Maphumulo, is the departed chief's widow and the current one's mother.

Census data for that broader municipality, called Mkhambathini, give some insight into the demographics of the area that includes Maqonqgo. Approximately 80 percent composed of rural communities such as Maqongqo, Mkhambathini is 95 percent black African, with isiZulu the first language of over 80 percent of the population. Some 54 percent of the adult population was not economically active at the time of the census, and of the economically active portion, 10 percent was looking for work but as yet unemployed. Over half of Mkhambathini residents live in informal housing and almost 35 percent lack electricity for indoor lighting. Less than 15 percent have indoor plumbing and less than 10 percent a flush toilet. Regarding marriage, almost half of Mkhambathini households are female-headed, indicating very low rates of marriage across the municipality.

As a rural community, Maqongqo's economic deprivation roughly tracks the levels for Mkhambathini as a whole. Importantly, however, many Maqongqo residents perceive it as a somewhat less difficult place to live than other villages of the region. Several participants' families had moved to Maqongqo in the preceding two and a half decades, many emphasizing the relative infrastructural advantages that made daily life, including accessing jobs in town, easier there than elsewhere. To be sure, this infrastructure remains unstable. For example, for a five-day stretch during my second fieldwork trip, much of the village lacked running water due to an accident while workers installed new pipe. Nonetheless, most residents find day-to-day subsistence reliable enough to imagine futures of growing homesteads and families. This may help explain why so many Maqongqo residents continue to see marriage as a feasible if difficult dream, and thus why the core processes of lobola have changed so little in recent years.

By contrast, in the economically poorer and more remote village of Msinga, some 100 kilometers to the north, researchers have noted that many locals are seeking state marital recognition (usually unsuccessfully) for relationships where lobola has begun but not yet finished (Cousins 2013). Perhaps economic fortunes in Msinga are so dire that completing lobola is now seen as virtually impossible. Moreover, because the local tribal council refuses to distribute homestead sites to most unmarried women, there may be pressure to recognize the early stages of lobola as marriage, allowing the couple to access a homestead together for their family. Meanwhile, in Maqongqo I encountered a number of unmarried women running their own homesteads, which they said they accessed in some cases through male relatives, including their minor sons, and in some, more recent, cases on their own. Maqongqo's history of more progressive approaches to chieftaincy seems to have produced relatively less patriarchal approaches to customary law, which might have eased pressure on marriage by providing ways outside it to access homesteads (see also Claassens and Smythe 2013). 
Fully understanding the causal factors that condition whether marriageformation customs persist or change in particular settings would require systematic, comparative research across multiple cases. Here I thus focus less on why marriageformation customs have persisted in Maqongqo and more on how they have responded there to post-apartheid economic, political, legal, and cultural pressures. For this purpose, Maqongqo is a useful case because the cross-currents shaping African marriage throughout South Africa are especially visible there. The precise customs governing marriage formation in Maqongqo may not apply elsewhere, but the dynamics that produce those customs are likely to be of broader relevance. Closely looking at Maqongqo reveals the ways persistence is intertwined with, and even dependent on, strands of change that adapt the practice to changing understandings and needs, and how this adaptation unfolds through everyday actions by the full range of people involved in lobola's practice. Such everyday action is also key in Msinga, the village discussed above where the changes in custom are clearer and move in a different direction. In Maqongqo, most everyday actions continue to enact orthodox understandings that tie lobola to extended-family notions of marriage, reproducing lobola as a law-like feature of the landscape upon which a marriage's recognition depends. But some everyday actions maneuver within these constraints to enact newer, less-recognized forms of lobola behavior, helping create new symbolic resonances for the practice and thereby neutralizing potential threats to its authority presented by dyadic narratives of marriage.

\section{ENACTING MULTIPLE NARRATIVES OF LOBOLA IN CONTEMPORARY MAQONGQO}

\section{The Enduring Extended-Family Narrative}

As summarized above, the dominant narrative of lobola frames it as the process through which intended spouses' extended families become acquainted with each other and build ongoing relationships, and through which the bride is introduced to the deceased ancestors of the groom's family so she may join their homestead. Selfconsciously traditional, this narrative legitimizes lobola's ongoing presence in changing times, and more specifically legitimizes the authority of elder generations to shape their younger kin's marital choices. This is the story lobola tells about itself.

The extended-family narrative appeared repeatedly during my Maqongqo fieldwork, especially when I asked in the abstract about "African marriage," "customary marriage," or "lobola." Few elaborated this imagery more fully than a man I call Mkhulu Mabena, a retired elder in one of Maqongqo's most prominent families. When I suggested that many young men find paying ilobolo difficult today, he agreed. "How will they pay ilobolo? ... Because it's expensive, yeah. But it's necessary to pay ilobolo because a wife must be known in the house. When she is not known [by the ancestors], among we Zulus, even if she is dead she doesn't enter the family." ${ }^{18}$ For Mr. Mabena, the ancestral dimension of family life made lobola

18. Original isiZulu transcriptions of interview materials available upon request. 
essential despite its contemporary difficulties, which in his view derived from not only economics but also cultural and religious politics. Pointing at me, he said, "It's you [white people] who built this thing of churches ... that aren't in [Zulu] law. You made us forget.... Yeah, they made us forget, saying we must leave tradition so that I never sacrifice an animal, that we must not sacrifice animals, it's demonic." Dating this shift to the pre-apartheid period, Mr. Mabena even suggested that apartheid had mitigated the problem by "say[ing we] must return to our culture."19 But by then the influence of churches had taken hold, teaching Africans that "the father who begat you is a demon," and that "you [must] go tell him, 'Fuck off!' and throw him away." Christian churches' opposition to lobola and other African practices had insulted the community's deceased relatives because it was around these ancestors that such practices revolved.

Living relatives are also important to extended-family narratives of lobola and African marriage. For example, some weeks later I interviewed Mkhulu's second wife, Ma Hlengwa. ${ }^{20}$ She walked me through the process of a Zulu marriage, saying that once a man has finished school and obtained a job, ${ }^{21}$ he visits the family of the woman he wishes to marry, bearing gifts. He stands before her "father's people, the grandparents, the grandmothers, the mothers," and says "I request a woman, a wife." The bride-to-be sits demurely as an agreement is reached, then "he pays ilobolo for her and [they] marry." Ma Hlengwa's tidy story briskly ticked off the steps to marriage without a word for the delays most endure today. (The peripheral presence during our interview of her own new daughter-in-law, quietly bustling through her chores in the rooms around us, indicated such delays' absence in this relatively advantaged and well-connected family.) Where her husband had focused on the challenges of lobola, Ma Hlengwa focused on the problems of marriage. These, too, concerned the extended family more than the spouse.

If there is an argument or a problem in the house, the wife mustn't take it to another house or another family. It's a matter for this house because you, the wife, were bought as a wife. This is now your primary relationship.... A newly arrived wife ... if there is a problem we sit down and she says, "No, Ma, here I'm not treated well."

"Yes, wife, we hear you. We thank you for letting us know there is a problem and sitting with us. If there is a problem in this house, we don't want it going outside, just as we don't want someone from outside bringing their problems here."

19. The Afrikaans word apartheid literally means "separate development." Apartheid ideology framed "races" as radically culturally different from each other and the state as responsible for protecting and promoting this cultural difference.

20. Extended-family narratives of marriage are indexed in the practice of referring to married women as "Ma" followed by their natal family's surname. Thus, Ma Hlengwa's name here indicates that she was born to the Hlengwa clan but married into a different clan (i.e., the Mabenas). While all names in this article are pseudonyms, I use forms that track participants' preferred forms of address from someone occupying my social position (age, gender, social closeness, etc.) vis-à-vis them.

21. The insertion of these into the typical sequence for a Zulu wedding shows how even the most selfconsciously traditional narrations are touched by colonial and postcolonial transformations. 
Ma Hlengwa's pat narrative drew sharp boundaries protecting family privacy from the outside world, grounded in clear expectations of smooth intrafamily communication. Outsiders may relay the wife's concerns should that not be true, but only in a way that respects her new family's privacy and authority.

Importantly, the husband of Ma Hlengwa's abstract narrative disappeared immediately upon paying ilobolo, unnamed among the family members who gather to discuss the wife's concerns as she adjusts to her new home. Several minutes passed before he reappeared, tacked to the end of a list of people for whom Ma Hlengwa insisted the new wife must cook, clean, and gather firewood. The bride and groom's own relationship took center stage only in nostalgic scenes of courtship Ma Hlengwa painted later in the interview, of a boy playing guitar by the river while his beloved coyly refuses him. Even here Ma Hlengwa expected the couple's behavior to implicitly acknowledge the extended family's proper role in negotiating their marriage. "This was we in the olden times! Nowadays they don't go to all this trouble. They get on the phone saying 'Oh, oh, I love you!' in just one day. The girl likes to say about the boy, 'I'm going to tell him that I love him.' That's wrong!" To Ma Hlengwa, romance belongs in a deliberate process managed by the families and oriented toward potential marriage, not in an impulsive cell-phone conversation.

In its idealized form, this extended-family character of marriage is realized chiefly through lobola itself as it works through and on extended kinship relations. Many told me that the process begins with an early morning shout, "Sicela isihlobo esihle!" ("We request a good relationship!"), ${ }^{22}$ as the groom's negotiators arrive bearing gifts to the bride's family's gate. The bride's father or other male relative invites the negotiators into the living room while the bride and her women kin cook the celebratory meal in the kitchen, and negotiations commence. If a deal is reached, the negotiators return to the groom to secure his assent, upon which he begins to gather and pay the gift of cattle-whether they "travel on foot" as actual cattle or "in the pocket" as cash-that constitute the process's core. An umembeso ceremony at the bride's home marks ilobolo's start and, often many years later, an umbondo ceremony at the groom's home its end. ${ }^{23}$ Both celebrations feature plentiful gifts from one family to the other, typically including a blanket, shirt, or apron for every individual in the extended family and even in neighboring homesteads, ${ }^{24}$ each recipient laying down on a mattress in the yard then "waking" to discover the gift placed upon her body and celebrating with a playful dance and ululation. Through this process the families build a deeper relationship, knowing each other well by the time of the actual wedding whose core moment is the delivery, as many call it, of the bride to her new home.

22. The following description is the one I heard most frequently, but some respondents shared what they understood to be ethnic, regional, or familial variations.

23. One participant insisted the umbondo need not occur at the end of ilobolo, but all others who discussed it placed it there.

24. Two middle-aged women complained privately to me that families give too many gifts nowadays, creating ostentatious performances that further pressure poorer families who have difficulty completing marriages. 
This notion of a bride's moving from one family to another is the fulcrum around which an extended-family narrative of marriage turns. Such transitions can be difficult in any cultural context, and here this transition requires managing relatives both living and dead. The spirits of deceased ancestors can be notoriously cantankerous, especially when someone inappropriate is in their home. This was vividly demonstrated when my host family invited me-but not the mother's unmarried, live-in partner- to witness a goat sacrifice requesting the ancestors' help with a family problem. In the round hut where my host mother usually slept, a traditional healer burned herbs and called upon the ancestors to approach while a son and a nephew ${ }^{25}$ slit the goat's throat, bleeding it into a wintergreen enamel bowl in the center of the floor. When I later asked why I could attend but her partner could not, my host mother told me the ancestors were happy to see me as a guest of the family, ${ }^{26}$ but that his presence would anger them. They don't like boyfriends, she concluded, covering her face as she trailed off into nervous laughter. ${ }^{27}$

It is lobola that prevents such ancestor displeasure at the similar presence of an unmarried woman in their home because, aware that their descendants paid her ilobolo, they see and, to use Mr. Mabena's term, "know" her as a wife. Regarding living relatives, ilobolo's completion also pushes the bride's relationship with her birth family into the background. ${ }^{28}$ When Ma Hlengwa worried about a new wife taking her troubles to outsiders, she was probably referring to these birth relatives. Although nosy neighbors were also a likely concern, her insistence that "this is your primary relationship" implicitly invoked the birth family who had been the wife's primary relationship before her marriage. If she approaches these now-outsiders, they must relay her concerns directly back to her married family, an obligation it is easy to imagine as arising out of the cattle they received for her marriage.

This is obviously a patriarchal narrative, an observation to which Ma Hlengwa's description of the wife as having been "bought" (-thengiwe in isiZulu) may appear a crude exclamation point. While justified, such an inference needs further clarification. A new wife is doubtless near the bottom of the family hierarchy, at least among adults, but in the Mabenas' household she is not treated as a totally powerless commodity. (In other households she may well be.) Ma Hlengwa emphasized that a new wife would receive the family's gratitude for raising her concerns in a family meeting, and my private conservations with young women in their family led me to believe they did in fact observe this principle.

25. The son of her paternal female cousin, who according to more traditional Zulu ways of figuring kinship is her sister. She and her cousin are also very close emotionally.

26. It is possible that being a non-Zulu person made my presence more or less irrelevant, not fully a person cosmologically speaking. It is also possible my host mother did not want her partner at the ceremony for her own personal reasons. By the time I returned in 2014, she had kicked the "rude" (uyadelela) partner out of her home.

27. If my host mother and her partner were married, this ceremony likely would not have taken place in this household since she would have moved into her husband's homestead and then, ideally, their own home. But in a twist caused in part by customary kinship rules, she became the custodian of her father's household or, in her words, "the man of the house" (indoda yasekhaya) because she was the only one of her siblings not to marry.

28. This is another point that reflects colonial law influence, as Shepstone's regulations attempted to sever wives' legal ties with their families of birth. 
In other words, the patriarchy typically enacted in the exchange of "wives for cattle" (Kuper 1982) is not best understood as an instrumental purchase of an object with cash. Rather, lobola densely encodes a rich range of semiotic associations that facilitate its enactment of extended-family narratives of African marriage. As already noted above, the cash in a contemporary ilobolo transaction is still usually called cattle, differentiating this cash from other currency (Comaroff and Comaroff 1990). Cattle are key prestige markers and vehicles of cosmological significance (Dlamini 1983, 227). Historically, these meanings were directly linked to the prevailing precolonial gender order in which men tended cattle while women raised crops, a division of agricultural labor semiotically mapped onto women's capacities for childbearing and human reproduction (Guy 1990). The exchange of wives for cattle drew meaning from this opposition by traversing it, extending a family into the future by securing the reproductive capacity of a wife born to a different family line (Kuper 1982).

The strictest dimensions of this gender framework diminished long ago; for example, many researchers report that ilobolo is rarely linked to women's reproductive capacity today, in part because single motherhood has become so widespread (de Haas 1987; Rudwick and Posel 2014). ${ }^{29}$ Yet the basic notion remains that, through cattle, a woman travels from the family line of her birth to the new one of her marriage, creating a link between the two families (Guy 1990). In this way, extended-family narratives of African marriage enact a patriarchy that is very real, yet more complex than it may appear at first blush. More dyadic narratives of marriage, meanwhile, have complicated the gender politics of African marriage even further, often helping circulate norms of gender equality.

\section{Emerging Dyadic Narratives}

Dyadic narratives of marriage abounded in Maqongqo, especially among the young. I asked all unmarried respondents to describe what they imagined marriage might be like. A young man I call Jabulani Ndaba responded:

Everything if you are careful starts between the two of you. You treat each other well, you listen to each other, you love each other, you're married. Nothing will come between you and split you up. 'Cause you made your vows in church in front of a preacher ... no person enters between us; we don't need a third person. So [if] we have a problem we just talk about it. There's never any need for it to come about that a person says, "Me, I'm the head of the house, right, I'm the head of the house, I'm the boss of the house." No, both of us are equal. We listen. If your wife comes saying, "Husband, it's like this. I ask that we do it this way, I don't know if you see it that way [also]?" You look at [her] suggestion, "OK, let's do

29. A man by whom a woman gets pregnant is often asked by the family of the woman to pay a small beast-for example, a goat - to atone for his transgression and legitimate his family line's claim to the child. Called inhlawulo in isiZulu, this has become perhaps the most common family-related payment in southern Africa, even as lobola continues to dominate the ways Africans imagine such customary payments. Given its frequency, more research on inhlawulo is urgently needed. 
your idea. You know I see that we [should] do it that way." That would be very right.

Jabulani dreamed of an intimacy that was explicitly dyadic (as well as gender egalitarian, to which I return below). "No person enters between us," he said. "We don't need a third person." Many others began with the image of a house in a yard-surrounded, in one respondent's laughingly deliberate English, by a "white picket fence." 30 Despite their tension with extended-family narratives of African marriage, such narratives have a long history in southern Africa. Mark Hunter (2005) has pointed out the highly elaborate nature of historic Zulu courting rituals (see, e.g., Krige 1957), and the idealized account of marriage in Maqongqo, which Ma Hlengwa invoked above, which begins with a young man who "-shela"s (literally "burns for") a woman with sweet talk until she eventually "-qoma"s ("chooses") him (see Hunter 2005). In the colonial period, migrant laborers began to write love letters home whose public nature-many recipients taking them to be read by a literate relative or neighbor-did not efface their intimately romantic contents (Breckenridge 2000). Similar sentiments appear today in Facebook, WhatsApp, and text messages.

Another thread of the dyadic narrative of marriage can be found in the ways many respondents idealized monogamous relationships. Although many young people today maintain multiple romantic relationships (Hunter 2010), women quietly and men boastfully, almost all my young respondents firmly opposed polygynous marriage, at least for themselves. Young women were particularly vehement, worrying polygyny would foster unfairness and uncertainty in their homes. Bathabile Mncuseni and her sisters, for example, were astonished to learn in our interview that the government would now recognize multiple wives. "It's bad. I definitely don't like it," Bathabile said. "You can go out and just marry a married man, here you see his wife and you go marry him? He'll marry another one after you."

Many young men I interviewed also disdained polygyny, frequently arguing that, although perhaps appropriate in the past, polygyny was no longer workable today thanks to the economy and HIV/AIDS. I chatted about this one morning with Hlubi Shangase as his friends shared a smoke around the corner, just out of earshot. The firstborn son of a polygynous family, Hlubi was adamantly opposed to polygyny for himself. "They say we mustn't lose our culture. That thing in Zulu culture where a man must be with more than one wife. But no, me, no." Earlier he had explained his devotion to his girlfriend and mother of his child. "You see, if you have a person who loves you, you must respect that person... Things have changed. It was better in the past [having multiple wives] because, of course, there weren't all these things that are here now. I'm thinking especially, you see, of HIV.... It's incurable, a very bad thing. It's better maybe that the person [you're with] not be so afraid." Focusing here on HIV's consequences not so much for

30. Of course, the respondent may have used this phrase in order to communicate with me, a researcher from the United States where the image originated. My aim here is not to identify his one true desire around marriage, but simply to document that individualist narratives of marriage are readily available to and intelligible by Maqongqo residents. US media and the tropes they carry are part of that circulation. 
himself but for his wife's emotional well-being, Hlubi framed polygyny as an impediment to emotional and physical health between husband and wife.

Dyadic narratives of marriage tended to emphasize the two spouses as individuals, and another individualist theme in many interviews was the strong conviction that marriage was a matter of autonomous choice. For example, Susan Gaxa, a warm neighbor and strict mother in her mid-fifties, fondly remembered her divorce, her moonbeam face breaking into triumphant laughter as she told me the story. She said no more about her marriage other than that it had been very difficult. When she decided to leave, she received help from the white couple in whose home she had long worked, whose connections to the local university's law faculty helped her find a free law clinic to draw up the divorce papers. Not wanting to see her imminent ex-husband ever again, Susan declined to fight for any property and simply signed papers that the lawyers then sent to him. Several weeks later the court date arrived. Her husband failed to show, and in a flash it was over.

I asked Susan whether her own, quite tradition-minded mother disapproved of the divorce. "It's my choice!" she firmly responded. His family, for their part, never asked that she return the ilobolo. This may indicate some awareness by his kin of her treatment, but more likely it was never even considered, for by many accounts the return of ilobolo has become rare (Burman and van der Werff 1993; Hunter 2010; see also Dlamini 1983, 228). In the past, returning ilobolo after a marriage's dissolution enacted, in reverse, the extended-family and patriarchal symbology of African marriage, acknowledging the groom's family's loss of a wife and placing the responsibility for that loss on the wife and her family. ${ }^{31}$ While more research is needed to understand exactly what the decline of ilobolo returns signifies, ${ }^{32}$ it may itself indicate the rise of individualist understandings of marriage as a personal choice. Whatever dynamics might have driven the lack of such return in Susan's case, her marriage, which had begun with intertwined Zulu and Christian rites, was cleanly dissolved by a civil court; Susan even legally reassumed her birth surname to allow her, under cultural rules, to be buried in her own homestead instead of her ex-husband's. 33

Susan strongly believed that the same autonomy she enjoyed in divorcing her ex-husband was everyone's right when it came to marriage. Indeed, she even passionately supported the right for someone to choose a same-sex spouse, in part because she had grown over the years to know and love the gay son of the family for whom she worked. Her opinion on this was more widely shared in my research than most existing accounts of attitudes to LGBT rights in South Africa would predict. While hardly any of my 2011 participants had heard of the RCMA, everyone

31. If the marriage's dissolution were imputed to the groom or his family, such return was not expected. Return was the default assumption, however.

32. One causal root of the decline is the rise in cash payments, as cash is more likely to be spent than was once true of cattle (Burman and van der Werff 1993). This says little about how people understand the decline, however.

33. Importantly, Susan's access to such options depended on the unusual contingencies of her employment. I met only one other divorced person in my fieldwork, who, heeding advice from two Catholic priests, reluctantly signed papers sent by her husband in order to protect her property rights but who still considered herself married in both culture and faith. 
knew of the new law authorizing state recognition for same-sex marriages. Most disapproved, but a significant minority supported the law, often saying that they did not personally like homosexuality but saw it as someone's rightful, free choice in a democracy. ${ }^{34}$ One woman in her twenties directly connected this to images of romantic love's irreducibly individual nature, suggesting that a person could not possibly control whom she or he loved. "That's the way they were created," she said. "It's the way they like to be in love." I more fully consider possible explanations for this support in other work (Yarbrough forthcoming), but what is important here is how it flowed out of a broader sense that marriage should be an individual choice. Similarly, many of those opposed to polygyny were careful to say that they did not oppose it for others, should it be their free choice.

For many participants, individual autonomy was not only marriage's ideal condition but also its imagined outcome. In particular, young participants often explicitly framed marriage as a kind of escape from their families of origin. For example, a man in his thirties I call Nkinsela Mbhele expected marriage to help free him of financial obligations to his mother.

You see, if I can get a job now, I'll go and work for my mother [who] will ask one month from me. My wife, I mean my fiancée, will want one month from me. Everybody. But once I marry someone, they can see that I've got my own house, I've got my own responsibilities.

Yeah, I'll give them the money I give them, but I won't be forced because now I've got my own house, I've got my own responsibility. I must look after my kids, my children, and after my wife. But when I come here, my mother doesn't have mealie-meal [i.e., cornmeal] or maybe rice, I buy that thing for her. But she mustn't expect every time I buy it because I've got my other commitment now.

There is a certain irony in Nkinsela's statement, his mom's current claims frustrating his ability to complete ilobolo and thereby, in his telling, to escape those claims. Yet most of his younger contemporaries also imagined marriage as a utopian autonomy from the parental obligations and discipline under which many now chafe well into their thirties and beyond. ${ }^{35}$

Often, this emphasis on autonomy was tightly linked to a prominent current of belief in gender equality. Although dyadic narratives of marriage certainly do not require gender-egalitarian attitudes, many younger participants saw the two as

34. My status as a white American might have shaped these responses. Moreover, although I did not disclose my own gay sexual identity during my fieldwork, some participants might have suspected it and shaped their responses accordingly. Nonetheless, these possibilities support my point here, which is simply that pro-LGBT discourses rooted in ideals of individual autonomy do circulate in Maqongqo. Moreover, results of the first nationally representative in-depth survey of LGBTI identification and attitudes in South Africa found results for the country remarkably similar to what I report here. In that survey, over 70 percent of respondents reported they found same-sex marriage morally wrong (Sutherland 2016, 37), but 51 percent believed gay and lesbian South Africans deserved human rights protections and only 21 percent said they wanted constitutional protections for sexual orientation removed (46).

35. As it happens, the woman for whom Nkinsela was paying ilobolo at the time of the interview later passed away, leaving their marriage-in-progress another one punctured by death. 
linked. For example, Jabulani, whose deeply dyadic image of marriage I quoted above, continued in this way:

[For example, imagine] a situation when I go to buy a TV. It can't be that I'm the father, I'm the head of the family, [so] I will go buy a TV. [And your wife replies,] "No, husband, maybe you start with a stove because the way I'm cooking now is a pain."

[And I respond,] “No, I have spoken, my word is final!” No, it doesn't work that way. It worked that way in the past. [But] the times have changed.

According to Jabulani, a man who today declared himself the head of the house would risk splitting up the marriage and breaking the couple's vows to each other before God. Perhaps recalling his own unmarried mother's struggles, Jabulani tightly linked a marriage's persistence to relative gender equality (if not, as the "stove" and "TV" references reveal, total gender neutrality). Implying that a wife may legitimately choose to leave a marriage should she find it unfair, Jabulani argued that the husband must also respect her role as the primary relationship in his life, not permitting any "third person" to come between them.

Jabulani's narrative typified what he and many others in my fieldwork called a $50 / 50$ marriage. Hunter $(2010,130)$ has traced the term, also widely encountered in his fieldwork, to a popular 2001 song by superstar local musicians Mandoza and Mdu. Ironically interpolating the international hit "Independent Women" by US R\&B girl group Destiny's Child, Mandoza and Mdu sarcastically instructed all those South African women newly liberated by the constitution to start paying their own way: "Let's go 50/50" (Mandoza and Mdu 2001). Apparently helping popularize the $50 / 50$ trope as a signifier of equality in love, this ditty's tones of antifeminist backlash were largely lost by the time of my 2011 interviews, and the term became the popular shorthand for legislative proposals in the 2010s promoting gender equity in political representation and employment (see, e.g., Skade 2013).

Many readers may consider lobola intrinsically hostile to 50/50 gender equality, but my research echoed other scholars in finding young women to be among lobola's strongest defenders (Hunter 2010; Rudwick and Posel 2014). Women's reasons were multiple and complex, with some giving more patriarchal and others more feminist reasons. Those who emphasized the latter saw lobola as the best means for guaranteeing that any husband they might marry would honor dyadic ideals of intimacy, autonomy, and equality.

These concerns often manifested in conversations about regional variations in ilobolo's amount, conversations extended even to me. "How much do you pay for ilobolo in America?" The question so surprised me the first time I heard it, at a barbecue celebrating the ANC's recent municipal election victories, that I was sure I had misunderstood. The stylish young women repeated themselves. Confused, I mumbled something about a ring. They laughed and dismissed me with predictions of surefire divorce. I would go on to be asked the question repeatedly, more frequently than almost any other. Over time, I started to see these exchanges as 
extending into new terrain a conversation heard almost every day in Maqongqo about regional variations in ilobolo's going rate. For example, Bathabile Mncuseni, whose mother had moved their family a few years back from a more remote village to the northwest, said one of the things she liked best about Maqongqo was ilobolo. Drawing her sisters, eavesdropping nearby, and her friend and my research assistant Nonjabulo into a spirited quartet of conversation, Bathabile told me, "I think that here [in Maqongqo] ilobolo is small, you see. The first cow is 5,000 [rand]. When we were there at home [in the previous village] it was 10,000 [rand]."

"Ha!" exclaimed Nonjabulo. "Just the beginning? Gosh, you all are truly suffering. People will definitely never get married there." From this vantage point, the extended-family narrative of lobola appeared constraining. In Maqongqo, by contrast, the assembled women estimated the amount for all ilobolo (not just the first cow under discussion here) usually totaled about 15,000 to 17,000 rand-at the time, approximately US $\$ 2,000$.

The young women approved of this amount with a Goldilocksian logic: high enough to mean something, but not so high as to prevent marriage. And, indeed, a number of women, young and old, told me about backstage actions they took to lower ilobolo's amount and facilitate their own or their children's marriages. For example, Nondumiso Zwane, a married woman in her mid-forties (and one of the youngest married women I met), described a kind of shuttle diplomacy her mother conducted between her and her father over her own lobola. "As for me, when [my mom] was saying [her father's ilobolo request] was very expensive, I said, 'Hey, no, no, it's so expensive, tell him to reduce it a little!" Breaking into loud laughter, she claimed such backstage negotiations were common. "[Women] talk, they whisper among themselves... Maybe my mother will whisper to me that, 'Oh, your father wants so much money.' If he's wanting 30,000 rands I say, 'No, no, Ma, never.” She saw this backstage whispering as essential for making lobola work. "At this time, this time right now, because they ask for 10,000 [just] for the isicelo [the first stage of ilobolo], it takes 20 years that a person doesn't get married." Not acknowledged in the orthodox, extended-family narrative of lobola, this backstage whispering is in fact an established component of lobola processes. In the language of Ewick and Silbey, it is an innovation that through repetition has become a stable part of lobola's legality.

Nondumiso situated this in a critique discussed above: that too many brides' families greedily drive ilobolo requests ever higher. This critique shows especially well just how intertwined extended-family and individualist understandings of marriage have become. On the one hand, the bride's father and elder male kin enjoy legitimate authority under extended-family narratives of marriage to negotiate lobola on behalf of the family. On the other, there is a widespread belief that many of these men exploit their legitimate authority for personal gain-and thereby obstruct the individual happiness of their daughters. The ideal, extended-family narrative of marriage enables both a particular kind of individualist behavior by fathers and a critique that fathers' individualism is obstructing their daughters' own happiness. In other words, the normative content of extended-family narratives-what it means to be a good member of an extended family-is itself shaped by individualist narratives that, drawing on the broader rise of gender-egalitarian discourses, frame daughters' desires as legitimate counterweights to fathers' authority. 
Different narratives of marriage institutionally associated with different, copresent legal systems simultaneously influence lay actors under their overlapping umbrellas, whose actions and understandings fuse these influences to create a hybridized understanding of marriage and family and an expanded collection of legible lobola behaviors. Such a complex intermingling of discourses does not produce consistent outcomes, for each player has at his or her disposal a varying array of ideological resources and a variable set of enabling and constraining circumstances. But it does shape the dynamics of such intrafamily struggles in ways that cannot be understood solely in terms of lobola's orthodox, extended-family narrative.

Nondumiso eventually won her struggle, her mother persuading her father to request a small amount of ilobolo provided the couple purchase their own furniture for the marital home-a settlement whose very terms underline the increasing importance of dyadic narratives of marriage. Over the course of the twentieth century it became increasingly expected that the bride's family would use some ilobolo to purchase a wedding gift of furniture for the new couple's home-the bed, wardrobe, and so forth. This gift, called the umabo, has become the element of lobola that most emphasizes the married couple's dyadic relationship, an erstwhile innovation that has now become, as Ewick and Silbey would suggest is possible, a stabilized element of lobola's grammar upon which Nondumiso and her family could further innovate in their own negotiations.

Nondumiso's backstage actions aimed to reduce her ilobolo in order to enable a desired marriage, but many women also worry that their ilobolo not be too low. For example, Zanele Mkhize, an unmarried woman in her mid-thirties, told me that when she was eighteen a man she loved had approached her mother requesting to marry Zanele. ${ }^{36}$ Her mother requested "a small ilobolo" of only 1,000 rands. "I felt bad," Zanele told me, "because this was the first person I loved.... I thought that this showed my mom was selling me." Like a too-large ilobolo request, Zanele's mother's too-small request similarly signified a commercialized transaction that undercut ilobolo's role as a symbol of love. Hunter's concept of provider love, introduced above, helps make sense of this reasoning. While colonial logics often viewed ilobolo as simply the commodification of women, and therefore the polar opposite of romantic love, Hunter suggests that isiZulu-speakers, and perhaps African southern Africans more broadly, came to see ilobolo and love as deeply intertwined, signifying a groom's capacity to earn cash in town to help the wife maintain his village homestead. By this logic, ilobolo was a kind of test for the groom's wherewithal and responsibility.

In Zanele's case, her then-fiancé initially performed well. "[Our daughter] got sick at two years old, and it looked like she needed an isiphandla [a bracelet of goat skin to protect her spiritually]. I phoned [my fiancé] and told him that his child was sick. He said I must relax and that he would do everything she needs for her." He was working in Johannesburg at the time and would only come to visit after each month's payday. But "he sent [Zanele] money saying we should take it to burn

36. Zanele's father had passed away long ago, and her mother handled these negotiations. While male kin usually still negotiate lobola, it is not uncommon in Maqongqo for single mothers to manage lobola negotiations for their daughters' marriages, either directly or by instructing their male kin what to say. 
herbs for our daughter [i.e., to hire a traditional healer] at his family's home" in another province. He continued sending money until the traditional healing process was completed. "After that I didn't see him at all! He didn't come here to our house; he didn't do anything. He would only phone and send money for the child." I asked what had happened. "When I asked him, he said he didn't love me any more." He stopped paying ilobolo because "he wasn't interested any more." One day a woman phoned Zanele from Johannesburg "telling me to forget him. She just said that I must forget him because he now has her. I was just quiet, telling myself that in my heart I must raise our daughter and forget him. Because now if I'm thinking of him our daughter will be affected." Some six months later he phoned to say that he was very sick. Shortly after that he died.

This sad story demonstrates the treacherous terrain women navigate as they try to form families in a very patriarchal context that limits their employment opportunities even more than men's. It also shows how lengthy lobola processes fit into the ways women experience and understand those difficulties. As sad as Zanele's estrangement from her fiancé had been, she figured that it reflected dangers intrinsic to a woman's life. Even the small ilobolo requested by her mother forced a kind of trial period in which Zanele could see the kind of spouse her fiancé would be. When he turned to another woman even as lobola was ongoing, Zanele acquiesced to the end of their relationship and refocused, as so many local women do, on her children. Such "lumping it," as dispute scholars would call it, allowing lobola agreements to drift away in the face of dispute, is perhaps one of the most common lobola-related behaviors today and is almost impossible to comprehend within the extended-family narrative.

Hunter's concept of provider love emphasizes breadwinning as a form of love, but Zanele's story shows that more romantic notions of love also circulate around lobola in contemporary isiZulu-speaking communities. As a lobola process wears on, a woman can observe not only a man's economic capacities and financial responsibility, but also his emotional and interactive habits in a context where (unlike before lobola's start) he has already secured from her a measure of commitment. Will he openly communicate with her? Share decision making? Refrain from violence? Women assess this in many ways, of which lobola is only one. But most young women nonetheless hoped against hope to unite provider and romantic love into ideal husbands of their dreams.

For while virtually all women wanted to marry, though virtually none would accept just any marriage. To the contrary, they worried deeply about a prospective marriage's quality. Women's definitions of a good marriage varied; virtually all wanted a husband with financial stability, but some also insisted on 50/50 equality, at least in making major decisions, while others desired a more gendered marital order. Yet almost all young women, like Zanele, strongly preferred single motherhood and continued life in their natal home over a marriage they did not trust. With the broader context affording poor African women very few options, high ilobolo fits this set of ordered preferences remarkably well. Its expense renders it almost by definition unachievable by men of limited means, while the time it takes offers an extended chance to evaluate a prospective husband's more interactional qualities. The very long engagements produced by contemporary lobola may even 
serve a similar function to the kind of premarital testing ground played by unmarried cohabitation in other contexts, including among white South Africans (Budlender, Chobokoane, and Simelane 2004; Mhongo and Budlender 2013; Posel and Rudwick 2014b).

Unmarried cohabitation itself, meanwhile, always triggered an embarrassed laugh when I mentioned it, and the census figures cited above found that only around 6 percent of Maqongqo adults reported themselves to be cohabiting. The most commonly cited reason in my interviews was cultural norms (see also Posel and Rudwick 2014b). Moreover, many women also worried cohabitation would give them all of marriage's vulnerabilities with none of its protections (see Goldblatt, Yose, and Mills 2001). Yet ilobolo's initiation triggers a change in status that renders the isiZulu term for unmarried cohabitation, ukukipita, no longer applicable in the eyes of most (Posel and Rudwick 2014b). ${ }^{37}$ Even among those many women who do not live with their groom during ilobolo's duration, visits become more frequent and sexual relations legitimized, giving women a more sustained look the kind of husbands their fiancés might become.

In these ways women's agency helps insert dyadic narratives of marriage into lobola's practice, at once broadening the range of legible lobola behavior and maintaining their strong support for an institution that leaves most of them, in the end, unmarried. Fully understanding lobola's persistence requires acknowledging women's key role in it. That said, one cannot forget the broader context of profoundly gendered disadvantage constraining this agency's scope. The very need to "test" a husband before marriage is engendered by widespread mistrust between women and men (Hunter 2010), and the preference for singlehood if a good marriage cannot be found crucially depends on good relations with one's natal family. For example, one woman whose family had all died explicitly told me she had agreed to a marriage she did not want, implying she had few other economically viable options.

Single motherhood, meanwhile, is a highly path-dependent family formation. Countless young women worried to me that new husbands would force them to leave their children behind, either rejecting them for cultural reasons or mistreating them. Even lobola's capacity to foster intimacy can be compromised by its extended-family entanglement: one woman, for example, worried the employed boyfriend she did not love would offer ilobolo before the boyfriend she did could find a job, placing her under intense pressure to enter a loveless marriage. This woman spoke both to her hope that love and lobola could be united and to the friction between extended-family and dyadic understandings of marriage in a community where both circulate widely.

\section{CONCLUSION}

Such hopes abide, keeping most young women supportive of lobola even as economic deprivation pushes their hopes out of reach. Most young men similarly

37. It is likely that some people counted in the census as "living together like married partners" had begun lobola and thus enjoyed this changed cultural status because census-takers recorded as "married" only those who had completed a wedding ceremony. 
continue to support the practice, even as they struggle under its burdens most directly. While space does not permit exploring young men's views more fully, many have come to see its difficulty as a virtue, a useful test of whether they can master the inscrutable ravages of the labor market and achieve adult masculinity. Although one wonders how long such a view can survive prolonged widespread unemployment, this is not the first time that young men have struggled under lobola's demands without endangering the institution itself. Increasing pursuit of unmarried cohabitation might represent another path to lobola's decline, and these rates have indeed crept up-but not as quickly as one might expect (Posel and Rudwick 2014b). Perhaps the most likely scenario would involve an increase in living together after partial payment of ilobolo but before a wedding ceremony, a possibility that would maintain lobola's authority in (yet again) transformed form. A variation on this possibility already exists in villages such as Msinga, discussed above, where at least some marital rights are clearly understood to begin accruing once lobola begins.

But for now lobola's authority is as resilient as ever. Like many other scholars, I find that this authority rests on diverse and even contradictory understandings of lobola's meanings and functions. Extended-family narratives of marriage continue to dominate lobola's explicit, orthodox representations, ritually enacted in its ceremonies and its normative accounts. Yet individualist and dyadic narratives of marriage have worked their way into lobola's actual practice. This is seen in the broad historical trends displacing ilobolo's payment from the groom's family to the groom himself and allowing the bride to know the terms of her own lobola, which have in turn opened the door to more ad hoc localized practices, especially by women, to negotiate lower ilobolo amounts behind the scenes and to treat lobola as a test of a groom's economic and emotional fitness for conjugal marriage.

These ad hoc innovations undoubtedly predate the post-apartheid era, but the constitutional values of equality and autonomy have emboldened many women who engage in them, fostering their belief that they may legitimately maneuver however they can to ensure their chances of a reliable and, for many, 50/50 marriage. At the same time, such women are deeply aware that they lack sufficient resources to press their cases in the costly and foreboding civil courts in town. Instead, most Maqongqo women maneuver within the terrain that is accessible, the terrain of lobola. By doing so they help keep lobola alive in a time of contested marital ideals, keeping one major constituency in its folds despite shifting desires that might otherwise threaten their faith.

At the same time, they introduce new meaningful practices into the lobola repertoire, practices that center on the relationship between potential bride and groom and that frame the extended family, and the groom himself, as a potential impediment to that relationship. This in turn helps construct a new relation between lobola and state law, as understandings of the latter infuse the practice of the former. Though nuanced and quiet, the impact of this transformation arguably touches more South Africans than even the RCMA legislation enacted by the state and aimed at precisely the same practices. Motivated by multiple narratives of marriage rooted in legal systems understood as distinct, these women help reconstruct a subtly changed pluri-legality. 
Meanwhile, young men sit most directly on the friction between dyadic dreams and extended-family obligations. With their participation definitionally required for lobola's persistence, further research on them would be especially useful. So, too, would further research on the meanings of other forms of ritual payment that undergird kinship relations, especially on widespread inhlawulo payments for children born out of wedlock. Fine-grained research into bridewealth's meanings in a range of locations would also be useful. No single setting can stand in for the whole country, and Maqongqo's proximity to urban Pietermaritzburg and history of relatively progressive politics undoubtedly distinguish it from more rural and/or patriarchal settings. So, too, does its setting in KwaZulu-Natal separate it from the other provinces where colonial law never so deeply emphasized bridewealth.

Extrapolating to the study of persistent nonstate legal systems in times of social stress, this article highlights the importance of studying not just the form of such systems or the substantive norms they administer, but also the forms and strength of authority granted them by those living under and within them. Actor-oriented approaches to legal pluralism have opened the space for such a project, while Ewick and Silbey's theorization of legality's production through the interplay of contradictory narratives helps illuminate the remarkable coherence nonstate systems can achieve even when embedded in a field where legal systems and norms themselves are both multiple and contested. By more explicitly tying these related scholarly threads together, my approach here begins to sketch a way to conceptualize and research the everyday production of pluri-legality, not merely as a collection of legal institutions and norms from among which individuals choose pragmatically, but more deeply as a landscape of meaning that motivates particular repertoires of action understood in particular ways. These patterns of meaningful action both reflect and construct pluri-legality, forming one major circuit along which pluri-legal systems persist via change.

\section{REFERENCES}

Albertyn, Catherine, and Likhapha Mbatha. 2004. Customary Law Reform in the New South Africa. In Gender, Citizenship and Governance: A Global Sourcebook, 51-60. Oxford: Oxfam Publishing.

Ansell, Nicola. 2001. "Because It's Our Culture!" (Re)negotiating the Meaning of Lobola in Southern African Secondary Schools. Journal of Southern African Studies 27 (4): 697-716.

Beinart, William, Peter Delius, and Stanley Trapido, eds. 1986. Putting a Plough to the Ground: Accumulation and Dispossession in Rural South Africa, 1850-1930. Johannesburg: Raven Press.

Bennett, T. W. 1994. The Equality Clause and Customary Law. South African Journal on Human Rights 10:122-30.

2004. Customary Law in South Africa. Lansdowne, South Africa: Juta.

Breckenridge, Keith. 2000. Love Letters and Amanuenses: Beginning the Cultural History of the Working Class Private Sphere in Southern Africa, 1900-1933. Journal of Southern African Studies 26 (2): 337-48.

Budlender, Debbie, Ntebaleng Chobokoane, and Sandile Simelane. 2004. Marriage Patterns in South Africa: Methodological and Substantive Issues. Southern African Journal of Demography 9 (1): 1-25.

Burman, Sandra, and Nicolette van der Werff. 1993. Rethinking Customary Law on Bridewealth. Social Dynamics: A Journal of African Studies 19 (2): 111-27. 
Carton, Benedict. 2000. Blood from Your Children: The Colonial Origins of Generational Conflict in South Africa. Charlottesville, VA: University of Virginia Press.

— 2006. "We Are Made Quiet by This Annihilation": Historicizing Concepts of Bodily Pollution and Dangerous Sexuality in South Africa. International Journal of African Historical Studies 39 (1): 85-106.

Casale, Daniela, and Dorrit Posel. 2010. The Male Marital Earnings Premium in the Context of Bride Wealth Payments: Evidence from South Africa. Economic Development and Cultural Change 58 (2): 211-30.

Claassens, Aninka, and Dee Smythe. 2013. Marriage, Land, and Custom: What's Law Got to Do with It? Acta Juridica 2013:1-27.

Comaroff, John L., ed. 1980. The Meaning of Marriage Payments. London: Academic Press.

Comaroff, John L., and Jean Comaroff. 1990. Goodly Beasts, Beastly Goods: Cattle and Commodities in a South African Context. American Ethnologist 17 (2): 195-216.

Cousins, Ben. 2013. Women's Land Rights and Social Change in Rural South Africa: The Case of Msinga, KwaZulu-Natal. Acta Juridica 2013:73-99.

de Haas, Mary. 1987. Is There Anything More to Say About Lobolo? African Studies 46 (1): 33 55.

de Souza, Monica. 2013. When Non-Registration Becomes Non-Recognition: Examining the Law and Practice of Customary Marriage Registration in South Africa. Acta Juridica 2013:239-72.

Dlamini, C. R. M. 1983. A Juridical Analysis and Critical Evaluation of iLobolo in a Changing Zulu Society. LLD diss., University of Zululand, South Africa.

Dubbeld, Bernard. 2013. How Social Security Becomes Social Insecurity: Unsettled Households, Crisis Talk and the Value of Grants in a KwaZulu-Natal Village. Acta Juridica 2013:197217.

Edin, Kathryn, and Maria Kefalas. 2005. Promises I Can Keep: Why Poor Women Put Motherhood Before Marriage. Berkeley, CA: University of California Press.

Essop Sheik, Nafisa. 2014. African Marriage Regulation and the Remaking of Gendered Authority in Colonial Natal, 1843-1875. African Studies Review 57 (2): 73-92.

Evans-Pritchard, E. E. 1931. 42. An Alternative Term for "Bride-Price." Man 31:36-39.

Ewick, Patricia, and Susan S. Silbey. 1998. The Common Place of Law: Stories from Everyday Life. Chicago: University of Chicago Press.

Goldblatt, Beth, and Likhapha Mbatha. 1999. Gender, Culture and Equality: Reforming Customary Law. In Engendering the Political Agenda: A South African Case Study, ed. Catherine Albertyn, 83-110. Johannesburg: University of the Witwatersrand Centre for Applied Legal Studies.

Goldblatt, Beth, C. Yose, and Shereen W. Mills. 2001. Cohabitation and Gender in the South African Context-Implications for Law Reform. Johannesburg: Gender Research Project of the Centre for Applied Legal Studies, University of the Witwatersrand.

Griffiths, Anne M. O. 1998. In the Shadow of Marriage: Gender and Justice in an African Community. Chicago: University of Chicago Press.

Griffiths, John. 1986. What Is Legal Pluralism? Journal of Legal Pluralism and Unofficial Law 24:155.

Guy, Jeff. 1990. Gender Oppression in Southern Africa's Precapitalist Societies. In Women and Gender in Southern Africa to 1945, ed. Cherryl Walker, 33-47. London: James Currey.

Hosegood, Victoria, Nuala McGrath, and Tom A. Moultrie. 2009. Dispensing with Marriage: Marital and Partnership Trends in Rural KwaZulu-Natal, South Africa 2000-2006. Demographic Research 20:279-312.

Hunter, Mark. 2005. Courting Desire?: Love and Intimacy in Late 19th and Early 20th Century Kwazulu-Natal. Passages 2 (June). http://quod.lib.umich.edu/p/passages/4761530.0010. 016?rgn = main;view $=$ fulltext (accessed December 22, 2016).

2010. Love in the Time of AIDS: Inequality, Gender, and Rights in South Africa. Bloomington, IN: Indiana University Press.

Jean-Bouchard, Évelyne. 2014. The (In)visible Subject: Women's Normative Strategies in Eastern Congo. Journal of Legal Pluralism and Unofficial Law 46 (3): 357-73. 
Kelly, Jill Elizabeth. 2012. "Only the Fourth Chief": Conflict, Land, and Chiefly Authority in 20th Century KwaZulu-Natal, South Africa. PhD diss., East Lansing: Michigan State University.

Khunou, Grace. 2012. Money and Gender Relations in the South African Maintenance System. South African Review of Sociology 43 (1): 4-22.

Krige, Eileen Jensen. 1957. The Social System of the Zulus, 3rd ed. Pietermaritzburg: Shuter and Shooter.

Kuper, Adam. 1982. Wives for Cattle. London: Routledge \& Kegan Paul.

Lambert, J. 1989. From Independence to Rebellion: African Society in Crisis, C. 1880-1910. In Natal and Zululand from Earliest Times to 1910: A New History, ed. Andrew Duminy and Bill Guest, 373-401. Pietermaritzburg University of KwaZulu-Natal Press.

MacKinnon, Aran S. 1999. The Persistence of the Cattle Economy in Zululand, South Africa, 1900-50. Canadian Journal of African Studies/Revue Canadienne des Études Africaines 33 (1): 98-135.

Mamdani, Mahmood. 1996. Citizen and Subject: Contemporary Africa and the Legacy of Late Colonialism. Princeton, NJ: Princeton University Press.

Mandoza and Mdu. 2001. 50/50. Godoba. CCP Records.

Mbatha, Likhapha. 1997. How Black South Africans Marry. CALS Research Report. Johannesburg: Centre for Applied Legal Studies, University of the Witwatersrand.

McCann, Michael W. 1994. Rights at Work: Pay Equity Reform and the Politics of Legal Mobilization. Chicago: University of Chicago Press.

Merry, Sally Engle. 1988. Legal Pluralism. Law E Society Review 22 (5): 869-96.

Mhongo, Christine, and Debbie Budlender. 2013. Declining Rates of Marriage in South Africa: What Do the Numbers and Analysts Say? Acta Juridica 2013:181-96.

Mnisi Weeks, Sindiso. 2013. Women's Eviction in Msinga: The Uncertainties of Seeking Justice. Acta Juridica 2013:118-42.

Morrell, Robert. 2001. The Times of Change: Men and Masculinity in South Africa. In Changing Men in Southern Africa, ed. Robert Morrell, 3-37. Pietermaritzburg: University of Natal Press.

Mosoetsa, Sarah. 2011. Eating from One Pot: The Dynamics of Survival in Poor South African Households. Johannesburg: Wits University Press.

Murray, Colin. 1977. High Bridewealth, Migrant Labour and the Position of Women in Lesotho. Journal of African Law 21 (1): 79-96.

— 1981. Families Divided: The Impact of Migrant Labour in Lesotho. Cambridge: Cambridge University Press.

Myers, J. C. 2008. Indirect Rule in South Africa: Tradition, Modernity, and the Costuming of Political Power. Rochester, NY: University of Rochester Press.

Nkosi, Sebenzile. 2011. Lobola: Black Students' Perceptions of Its Role on Gender Power Dynamics. M.A. thesis, University of the Witwatersrand, South Africa.

O'Laughlin, Bridget. 1998. Missing Men? The Debate Over Rural Poverty and Women-Headed Households in Southern Africa. Journal of Peasant Studies 25 (2): 1-48.

Posel, Deborah. 1995. State, Power and Gender: Conflict Over the Registration of African Customary Marriage in South Africa C. 1910-1970. Journal of Historical Sociology 8 (3): 223-56.

Posel, Dorrit, and Daniela Casale. 2013. The Relationship Between Sex Ratios and Marriage Rates in South Africa. Applied Economics 45 (5): 663-76.

Posel, Dorrit, and Stephanie Rudwick. 2014a. Marriage and Bridewealth (Ilobolo) in Contemporary Zulu Society. African Studies Review 57 (2): 51-72.

. 2014b. Ukukipita (Cohabiting): Socio-Cultural Constraints in Urban Zulu Society. Journal of Asian and African Studies 49 (3): 282-97.

Posel, Dorrit, Stephanie Rudwick, and Daniela Casale. 2011. Is Marriage a Dying Institution in South Africa? Exploring Changes in Marriage in the Context of Ilobolo Payments. Agenda 25 (1): 102-11.

Rudwick, Stephanie, and Dorrit Posel. 2014. Contemporary Functions of Ilobolo (Bridewealth) in Urban South African Zulu Society. Journal of Contemporary African Studies 32 (1): 118-36.

Sachs, Albie. 1990. Judges and Gender: The Constitutional Rights of Women in a PostApartheid South Africa. Agenda 7:1-11. 
Schneider, David Murray. 1968. American Kinship: A Cultural Account. Englewood Cliffs, NJ: Prentice-Hall.

1984. A Critique of the Study of Kinship. Ann Arbor, MI: University of Michigan Press.

Semenya, Caiphus. 1996. Ziph'inkomo. The Best of Letta \& Caiphus. Columbia Records.

Shefer, Tamara, ed. 2007. From Boys to Men: Social Constructions of Masculinity in Contemporary Society. Lansdowne, South Africa: UCT Press.

Shope, Janet Hinson. 2006. "Lobola Is Here to Stay": Rural Black Women and the Contradictory Meanings of Lobolo in Post-Apartheid South Africa. Agenda 20 (68): 64-72.

Silbey, Susan S. 2005. After Legal Consciousness. Annual Review of Law and Social Science 1: $323-68$.

Skade, Thandi. 2013. Let's Go 50-50! Destiny Magazine November 11. http://www.destinyconnect. com/2013/11/11/lets-go-50-50/ (accessed December 22, 2016).

Steyn, Anna F., and Colin M. Rip. 1968. The Changing Urban Bantu Family. Journal of Marriage and Family 30 (3): 499-517.

Sutherland, Carla. 2016. Progressive Prudes: A Survey of Attitudes Towards Homosexuality $\mathbb{E}$ Gender Non-Conformity in South Africa. Johannesburg: Other Foundation.

Thomas, Lynn M. and Jennifer, Cole. 2009 Thinking through Love in Africa. In Love in Africa, ed. Jennifer Cole and Lynn M. Thomas, 1-30. Chicago: University of Chicago Press.

Turner, Bertram. 2015. Exploring Avenues of Research in Legal Pluralism: Forward-Looking Perspectives in the Work of Franz von Benda-Beckmann. Journal of Legal Pluralism and Unofficial Law 47 (3): 375-410.

von Benda-Beckmann, Franz, and Keebet von Benda-Beckmann. 2006. The Dynamics of Change and Continuity in Plural Legal Orders. Journal of Legal Pluralism and Unofficial Law 53-54: $1-44$.

Walker, Cherryl. 1992. Attitudes to Lobola. Agenda 8 (13): 57-58.

Welsh, David John. 1971. The Roots of Segregation: Native Policy in Colonial Natal, 1845-1910. Cape Town: Oxford University Press.

Weston, Kath. 1991. Families We Choose: Lesbians, Gays, Kinship. New York: Columbia University Press.

Yarbrough, Michael W. 2015. Toward a Political Sociology of Conjugal-Recognition Regimes: Gendered Multiculturalism in South African Marriage Law. Social Politics: International Studies in Gender, State $\mathcal{E}$ Society 22 (3): 456-94.

Forthcoming. Love and Marriage: Lesbian and Gay Identities, Same-Sex Marriage, and Changing African Kinship Systems in South Africa. Manuscript under review.

\section{STATUTES CITED}

Native Administration Act 38 of 1927, Republic of South Africa.

Recognition of Customary Marriages Act 120 of 1998, Republic of South Africa. 